Summer 2012

\title{
The Human Right to Water: Will Its Fulfillment Contribute to Environmental Degradation?
}

Alezah Trigueros

Indiana University Maurer School of Law

Follow this and additional works at: https://www.repository.law.indiana.edu/ijgls

Part of the Environmental Law Commons, International Law Commons, and the Water Law Commons

\section{Recommended Citation}

Trigueros, Alezah (2012) "The Human Right to Water: Will Its Fulfillment Contribute to Environmental Degradation?," Indiana Journal of Global Legal Studies: Vol. 19 : Iss. 2 , Article 11.

Available at: https://www.repository.law.indiana.edu/ijgls/vol19/iss2/11

This Note is brought to you for free and open access by the Law School Journals at Digital Repository @ Maurer Law. It has been accepted for inclusion in Indiana Journal of Global Legal Studies by an authorized editor of Digital Repository@Maurer Law. For more information, please contactrvaughan@indiana.edu.

\section{$\Psi$}

JEROME HALL LAW LIBRARY

INDIANA UNIVERSITY

Maurer School of Law
Blooming ton 


\title{
The Human Right to Water: Will Its Fulfillment Contribute to Environmental Degradation?
}

\author{
ALEZAH TRIGUEROS*
}

\begin{abstract}
Human rights and environmental protection are two oftenoverlapping bodies of law, each of which by their nature seeks to take priority over other applicable law. For this reason, these two bodies of law often find themselves in tension with one another. This Note aims to illustrate the tension between human rights and environmental protection in the context of the recent push for a codified human right to water. My thesis is that ideally these two bodies of law should balance each other out-a human right to water would be subject to environmental safeguards, and, likewise, conservation efforts would be subject to human rights concerns-but when this balancing does not occur the consequences would be potentially severe.
\end{abstract}

\section{INTRODUCTION}

On July 28, 2010, the United Nations General Assembly adopted Resolution 64/292, which declares, "[s]afe and clean drinking water and sanitation is a human right essential to the full enjoyment of life and all other human rights."1 Resolution 64/292 "call[s] on States and international organizations to provide financial resources, build capacity and transfer technology, particularly to developing countries, in scaling up efforts to provide safe, clean, accessible and affordable drinking water and sanitation for all."2 The General Assembly stated

* J.D., 2012, Indiana University Maurer School of Law. I would like to thank Professors David Fidler and Timothy E. Lynch for their guidance.

1. General Assembly Declares Access to Clean Water and Sanitation is a Human Right, UN NEws CENTRE, July 28, 2010, http://www.un.org/apps/news/ story.asp?NewsID=35456\&Cr=SANITATION\#.

2. Press Release, Sixty-fourth General Assembly, General Assembly Adopts Resolution Recognizing Access to Clean Water, Sanitation as Human Right, by Recorded

Indiana Journal of Global Legal Studies Vol. 19 \#2 (Summer 2012)

(C) Indiana University Maurer School of Law 
that the human right to water has not been fully recognized despite repeated references to such a right in various United Nations and other international instruments. ${ }^{3}$

On September 30, 2010, the United Nations Human Rights Council (UNHRC) affirmed and clarified this decision. ${ }^{4}$ The UNHRC declared that the right to water and sanitation already existed-as it is derived from the right to an adequate standard of living and is thus contained in existing human rights treaties-and that States had the primary responsibility to ensure full realization of this right. 5 The UNHRC further stated that the right to water and sanitation is therefore legally binding, whereas the General Assembly's resolution had recognized the right but did not specify that it entailed legally binding obligations. ${ }^{6}$

The right to water is one of the most, if not the most, environmentally consequential human rights in international law because it involves human access to a resource that is vital not only to humans but to all living things in the global ecosystem. The 1997 "Comprehensive Assessment of the Freshwater Resources of the World" (U.N. Freshwater Assessment), completed at the request of the United Nations Economic and Social Council, attempted to summarize the global status of water:

Water use has been growing at more than twice the rate of the population increase during this century, and already a number of regions are chronically water-short. About one-third of the world's population lives in countries that are experiencing moderate to high water stress partly resulting from increasing demands from a growing population and human activities. By the year 2025 , as much as two-thirds of the world population could be under stress conditions.?

Elaborating on the issue of increasing consumption, the Secretary General reported:

Vote of 122 in Favour, None Against, 41 Abstentions, U.N. Press Release GA/10967 (July 28,2010 ).

3. Id.

4. E.g., Right to Water and Sanitation is Legally Binding: UN, RIGHT VISION NEWS, Oct. 5, 2010 (Pak.).

5. E.g., id.

6. E.g., id.

7. U.N. Secretary-General, Comprehensive Assessment of the Freshwater Resources of the World: Rep. of the Secretary-General, \2, U.N. Doc. E/CN.17/1997/9 (Feb. 4, 1997). 
Currently, humans are using about half the 12,500 cubic kilometers of water that is readily available. Given an expected population increase of about 50 percent in the next 50 years, coupled with expected increases in demand as a result of economic growth and lifestyle changes, this does not leave much room for increased consumption. ${ }^{8}$

This growing water use is due to "increasing consumption of food and industrial goods produced using water," and "increasing demands for water supplies for industrial development, hydroelectric generation, navigation, recreation and domestic use." 9 The result is that "at least one fifth of all people do not have access to safe drinking water, and more than one half of humanity lacks adequate sanitation." 10

However, the problems created by water stress are not limited to harm to human beings. "Water demands are so high that a number of large rivers decrease in volume as they flow downstream" and many groundwater resources "are being drained faster than nature can replenish them." 11 Not only do downstream users face shortages, but ecosystems suffer, both in rivers and in adjacent coastal areas:

High withdrawals of water, and heavy pollution loads have already caused widespread harm to a number of ecosystems ... Reproductive failures and death in various wildlife species, particularly at higher levels in the food chain, are being reported in various regions of the world. In addition, rising human demands will put increasing pressure on ecosystems. As more water is withdrawn for human uses, there is an increasing need to make certain than an adequate water supply to wetlands, lakes, rivers and coastal areas is maintained to ensure the healthy functioning of ecosystems. ${ }^{12}$

[Furthermore, a] growing number of the world's rivers, lakes and groundwater aquifers are being severely contaminated by human, industrial and agricultural wastes. Not only does the pollution affect freshwater quality, but much of it flows into the world's oceans, threatening marine life. The future health of the oceans
8. Id. ๆ 37 .
9. Id. ๆ 13 .
10. $I d$. 5 .
11. $I d$. ๆ 6.
12. Id. \ 8 . 
depends heavily on how the freshwater systems are managed. 13

In essence, "water needs to be left in rivers [and lakes] in order to maintain healthy ecosystems." 14

The core issue from which these numerous problems stem is the fact that the current and projected rate of human use and consumption of water resources is not sustainable:

[I]n many countries, both developing and developed, current pathways for water use are often not sustainable. There is clear and convincing evidence that the world faces a worsening series of local and regional water quantity and quality problems, largely as a result of poor water allocation, wasteful use of the resource, and lack of adequate management action .... A number of studies by United Nations agencies show that many countries lack the capacity to carry out comprehensive water resources assessments that include not only water quantity and quality but also other factors such as changes in population and industrial development. There is a need for countries to strengthen their capabilities in this regard in order to be able to meet more effectively current and future stresses on their water resources. ${ }^{15}$

The U.N. Freshwater Assessment concludes,

The world faces many challenges over use of the environment as a source of natural resources and as a sink for wastes. Water has to be considered one of the main issues facing the world. It is as important as atmospheric change, deforestation, protection of biodiversity and desertification, all of which are linked to water management. ${ }^{16}$

Considering the necessity of potable water to human health and wellbeing, it is not surprising that water stress has become a central focus in
13. Id. I 7.
14. Id. $\ 37$.
15. Id. ๆๆ $1,11$.
16. Id. ๆ 24. 
current human rights dialogue. However, as the U.N. Freshwater Assessment demonstrates, water stress produces significant and farreaching environmental consequences in addition to the direct impacts on human health and well-being. While some human rights advocates and scholars are optimistic that environmental concerns can be addressed within the human rights framework, I question whether a human right to water is capable of encompassing the broad and significant environmental concerns outlined in the U.N. Freshwater Assessment.

The U.N. Freshwater Assessment demonstrates the dire state of the planet's freshwater resources, yet a human right to water could circumvent competing environmental concerns and decide where water should be allocated without regard to sustainability. In their textbook, International Environmental Law and Policy, David Hunter, James Salzman, and Durwood Zaelke pose the question: "Given that freshwater biodiversity is by most estimates the most endangered category of biodiversity in the world, would you still agree that promoting a human right to water is appropriate?"17 With the utmost respect for the importance of potable water to human health and the right to life, I urge that promoting a human right to water is inappropriate absent adequate environmental safeguards.

This Note demonstrates that, given the current state of international environmental law, a human right to water could produce environmentally damaging consequences. My concern is that international environmental law, in its current state, is not capable of adequately protecting the integrity of the planet's freshwater ecosystems against the increased consumption which would result from realization of a right to water. My thesis is that it is essential to balance human rights and environmental protection against one another. Uneven development between these two bodies of law will produce severe consequences. Part I provides a brief history of international environmental protection of freshwater resources-outlining the traditional law of international watercourses and some more modern applicable international environmental law principles-and assesses whether these bodies of law are capable of adequately protecting the integrity of freshwater ecosystems. Part II chronicles the development of the human right to water, discusses the substantive content of that right, and outlines the right's monitoring and compliance mechanisms. This Section will also show that the environmental issues discussed in the U.N. Freshwater Assessment are not addressed by recognizing the human right to water, which focuses entirely on human health and well-

17. DAvid HuNTER, JAMES SALzMAN \& DURWOOD ZAELKE, INTERNATIONAL ENVIRONMENTAL LAW AND POLICY 893 (3d ed. 2007). 
being. Part III concludes this Note by attempting to address the following questions: What level of protection can we expect for freshwater ecosystems, given the current state of international environmental law, if the human right to water is realized? Is enforcing the human right to water the best avenue for addressing global water stress issues? Will efforts to fulfill a human right to water contribute to environmental degradation?

\section{International ENVIRONMENTAL Protection of Freshwater RESOURCES}

\section{A. The Law of International Watercourses}

Freshwater resources have long been a topic of international law. The law of international watercourses is an extremely old body of law that deals with the development and optimal use of freshwater resources such as lakes, rivers, streams, and channels. ${ }^{18}$ This body of law has developed primarily in the transnational context, with transnational disputes over watercourses producing numerous treaties and a rich body of customary international law. ${ }^{19}$ Thus, the law of international watercourses is primarily concerned with two broad issues: "(1) how should uses of the water in a transboundary lake or river be allocated between the two or more States of the watershed; and (2) what procedural rights and responsibilities accrue to States sharing a watershed."20

Although the law of international watercourses is pertinent to our discussion, in that it governs state use of freshwater resources, it is "a separate and distinct field from international environmental law," which will be discussed in the following section. ${ }^{21}$ While, as we will see, the modern trend in the law of international watercourses has been to incorporate international environmental law principles, the law of international watercourses is primarily concerned with the development and optimal use of watercourses, not environmental protection. ${ }^{22}$

\section{Treaties Governing Use of International Watercourses}

From the sixteenth until the mid-twentieth century, hundreds of international agreements were negotiated to address the use and

18. See id. at 868 .

19. Id. at 845 .

20. Id. at 868 .

21. Id.

22. See id. 
management of transboundary watercourses. ${ }^{23}$ These treaties attempted to "ensure free navigation and allow shared use of the waters for fishing, agriculture or industry."24

In Europe, between 1648 and 1792, natural law principles competed with the common practice of using navigation provisions to enhance the economic positions of political victors. ${ }^{25}$ Peace treaties established major changes, such as openings and closings of rivers to navigation, while cooperative agreements dealt with issues such as navigation improvements and flood control. ${ }^{26}$ However, by 1804 the concept of freely navigable "watercourse states" emerged, which led to the organization of river commissions to administer international agreements and establish implementing regulations. ${ }^{27}$ "This trend of increasing the scope and sophistication of river commission regulations continued through the nineteenth century . . .."28 Outside of Europe, from 1830 to 1901 the development of colonial water treaties mirrored those of Europe. ${ }^{29}$

Codification emerged as a trend in 1887 when the Institute of International Law issued its first Regulation for Rules of Navigation on International Rivers. ${ }^{30}$ In 1921, the League of Nations issued the Convention and Statute on the Regime of Navigable Waterways of International Concern. ${ }^{31}$ At the same time, the river commissions "continued to refine their regulations on tariffs, tolls, river police, bridge construction, channel maintenance, non-navigational uses, and even certain types of environmental protection"; and, "as non-navigation uses

23. Id. at $849-50$.

24. Id. at 849 .

25. James L. Wescoat, Jr., Main Currents in Early Multilateral Water Treaties: A Historical-Geographic Perspective, 1648-1948, 7 COLO. J. INT'L ENVTL. L. \& POL'Y 39, 49-50 (1996), For example, the 1648 Treaty of Münster opened the lower Rhine to free navigation and trade, while simultaneously closing the Scheldt River to give Dutch merchants a competitive advantage over their commercial rivals. Id.

26. Id. at $52-53$.

27. See id. at 53-56. Two examples are the 1815 Congress of Vienna, which established a Committee of Navigation; and the 1856 General Treaty of Peace, which created a temporary European Commission to undertake navigation improvements and a permanent riparian commission for policing rivers. The Vienna Committee of Navigation adopted the principle of freedom of navigation for purposes of commerce and created a Central Commission to address common problems and produce reports. Id. at 54 .

28. Id. at 55.

29. See id. at 56-59.

30. See id. at 61-62.

31. Id. at 61 . This treaty focused primarily on water law and dealt with an even broader range of topics than its predecessors, including: "boundaries, non-navigational uses, arbitration, and international commissions." Id. 
expanded, [boundary commissions] acquired new responsibilities related to dam construction, water allocation, and pollution." 32

"[T] he League of Nations and [the] Pan American Union established a new institutional and geopolitical context for water agreements." 33 The League of Nations affected an important transition from river commissions to regional organizations by obtaining pan-European assent to the principle of freedom of transit and sponsoring studies and treaties facilitating the development of hydraulic power while protecting the interests of downstream states. ${ }^{34}$ Meanwhile, in the Western Hemisphere, the Pan American Union "championed policies related to health, sanitation, and cultural affairs" and promoted "integrated international management of navigation, industrial, and agricultural water uses." 35 Together, these organizations "sowed the institutional seeds for what would follow in the late 1940s under the auspices of the United Nations, the Organization of American States, and the World Bank."36

\section{Customary International Law of Watercourses: Incorporating Environmental Law Principles into Watercourse Management}

While the watercourse treaties primarily regulated navigational uses of international watercourses, customary international law developed to address non-navigational uses in response to conflicts over the use of shared watercourses. ${ }^{37}$ Initially, customary international law was believed to protect states' territorial sovereignty over resources within their jurisdiction. States were free to pollute, divert, and otherwise alter the natural properties of freshwater resources within their jurisdictions, even if this came at a cost to neighboring riparian states.

The Lake Lanoux Affair was a 1957 case between Spain and France, involving a disagreement over the use of the waters of Lake Lanoux, which was situated near the border between the two countries. 38 The French government wanted to build a hydroelectric dam on Lake Lanoux, which would require increasing the lake's size and diverting

32. Id. at 62 .

33. Id. at 64

34. Id. at 65-66.

35. Id. at 70 .

36. Id.

37. HunTER, SAlzMAN \& ZAELKE, supra note 17, at 850; Salman M. A. Salman, The Helsinki Rules, the UN Watercourses Convention and the Berlin Rules: Perspectives on International Water Law, 23 WORLD RESOURCES DEV. 625, 625 (2007).

38. HUNTER, SALZMAN \& ZAELKE, supra note 17 , at 850. 
water that usually moved from Lake Lanoux into Spain..$^{39}$ France proposed the construction of an underground tunnel that would restore to Spain the amount of water diverted with water of equal quality from a different French river basin. ${ }^{40}$ Spain argued that it was inherently wrong to alter the river basin's natural flow and structure and supplant that system with a man-made one, that this type of project required the consent of both governments involved prior to execution, and that for France to act without such prior consent from Spain would have been a breach of international law. ${ }^{41}$

The arbitration tribunal rejected each of Spain's claims, affirming the principle of territorial sovereignty over resources within a state's jurisdiction. The tribunal applied Article Eight of the Treaty of Bayonne Additional Act, which states that "[a]ll standing and flowing waters, whether they are in the private or public domain, are subject to the sovereignty of the State in which they are located .... Flowing waters change jurisdiction at the moment when they pass from one country to the other." 42 The tribunal held that water is a fungible item, which does not change its form to meet human needs, and that the type of diversion with restitution envisaged in France's project proposal would not alter Spain's state of affairs. ${ }^{43}$ And the tribunal found that, while France had

39. Lake Lanoux Arbitration (Fr. v. Spain), 12 R.I.A.A. 281 (Arb. Trib. 1957), translated in 24 I.L.R. 101, 101 n.2, 109-110 (1961).

40. Id. at 101 n.2, 107-110. Further, France proposed a "mixed Franco-Spanish Commission, with both sides equally represented, to ensure the control of the works as well as the regularity of the restoration of water." Id. at 110 .

41. See id. at 112-114. Spain argued that France's proposed action would affect the whole of the water system and the flow of the waters coming from Lake Lanoux ... would produce a modification of the physical features of the hydrographic basin ... would radically alter its structure from its source onwards by the effect of the total removal of the volume of water which now flows along its natural course ... [T] [Te water would no longer flow naturally in its own course, the physical cause of its present flowing being supplanted and replaced ... . [and] would transform the waters of the river basin which are common by nature into waters for the predominant use of one country, thus establishing a physical predominance which does not today exist, as is shown by the fact that the water flows today according to physical [natural] laws, whereas after the scheme has been completed its eventual equivalent will be restored solely by the work of the human will which abstracted it.

Id. Spain further argued that the "technical possibility of restoring the equivalent of the waters abstracted" would "not lessen in any way the profound transformation which the basin ... will undergo in its physical structure as a result of human interference with the flow of waters which hitherto have run naturally." Id. at 113.

42. Id. at $119-20$.

43. Id. at 125 . 
a duty to negotiate in good faith with Spain, this did not amount to a veto right for Spain. ${ }^{44}$

The principle of territorial sovereignty was reaffirmed in the 1966 Helsinki Rules on the Uses of the Waters of International Rivers [Helsinki Rules], which expounded the principle of equitable and reasonable utilization: "Each basin State is entitled, within its territory, to a reasonable and equitable share in the beneficial uses of the water of an international drainage basin." 45 Although the Helsinki Rules' equitable utilization principle is qualified by a standard of "reasonableness," the fact that the criteria for determining reasonableness includes factors such as past and current utilization of the resource ensures territorial sovereignty to upstream users. ${ }^{46}$

Even decisions that seemed to favor environmental protection were rooted in the principle of territorial sovereignty. For example, the Gut Dam Claims, allegations by the United States that the Canadian-built Gut Dam had caused damage to U.S. property, were arbitrated in 1967 and 1968. ${ }^{47}$ The Lake Ontario Claims Tribunal settled the arbitration in favor of the United States, finding: (1) that Canada, in its written correspondence, ensured compensation for any U.S. citizen whose property suffered damage due to the construction or operation of the Gut Dam and (2) that Canada's guarantee of compensation applied to the period when the disputed damage occurred. ${ }^{48}$ While the Gut Dam

44. Id. at 128 .

[O]ne must envisage the hypothesis in which the interested States cannot reach agreement. In such case, it must be admitted that the State which is normally competent has lost its right to act alone as a result of the unconditional and arbitrary opposition of another State. This amounts to admitting a 'right of assent', a 'right of veto', which at the discretion of one State paralyses the exercise of the territorial jurisdiction of another.

Id.

45. HELSINKI RULES ON THE USES OF THE WATERS OF INTERNATIONAL RIVERS, art. 4, in INTERNATIONAL LAW ASSOCIATION, REPORT OF THE FIFTY-SECOND CONFERENCE 484 (1966), available at http://www.mpil.de/shared/data/pdf/pdf/8helsinki_rules_on_the _ waters_of_international_rivers_ila.pdf. The Helsinki Rules were issued by the International Law Association (ILA), a scholarly, nongovernmental organization of international lawyers that aims to codify international law as it exists. While the ILA's rules and resolutions are not legally binding, they can potentially be used as powerful evidence of the existence of customary international law. Salman, supra note 37, at 628 .

46. HELSINKI RULES ON THE USES OF THE WATERS OF INTERNATIONAL RIVERS, art. 5, in InTERnational LaW ASSOCIATION, RePORT OF THE FTFTy-SECOND CONFERENCE 484

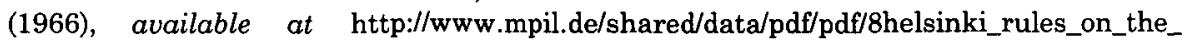
waters_of_international_rivers_ila.pdf; see also Salman, supra note 37, at 633-34.

47. Carl F. Goodman, Canada-United States Settlement of Gut Dam Claims: Report of the Agent of the United States Before the Lake Ontario Claims Tribunal., 8 I.L.M. 118, 119, 121 (1969).

48. See id. at 138-39. 
Claims have often been characterized as an example of strict liability being applied to extraterritorial environmental damage, Canada had voluntarily agreed to assume strict liability for any injury to U.S. citizens caused by the dam in exchange for the consent of the United States to the dam's construction. ${ }^{49}$ The tribunal simply interpreted and applied the provisions of the agreement, it never made any broader holding on State liability for extraterritorial environmental damage, and therefore the imposition of strict liability in the Gut Dam case is inextricably linked with Canada's consent to be held strictly liable.50 Thus, although the tribunal did order Canada to pay damages, it did so within the framework of Canada's territorial sovereignty.

Despite this longstanding adherence to the principle of state territorial sovereignty, as the trend toward conservation of water quality and ecological services began to emerge in the $1960 \mathrm{~s}$, international environmental law principles have begun to work their way into the customary international law of watercourses. The 1997 Gabćíkovo-Nagymaros Dam Project case demonstrates the-increased role for environmental appeals in watercourse conflict cases.

In 1977, Hungary and Czechoslovakia entered into a treaty for the joint construction and operation of a system of locks along the Danube River, which runs through both states, to generate hydroelectric power, improve navigation, and prevent flooding. ${ }^{51}$ However, in 1989 , facing intense criticism about the environmental impacts of the project, Hungary initially suspended and later abandoned work at Nagymaros. ${ }^{52}$

Canada enjoyed half a century of benefits as a result of, and based on, United States consent subject to this condition. There can be no doubt that Canada is bound by this condition, and that Canada must now pay compensation for damage or detriment to United States citizens caused by the construction and operation of Gut Dam. Id. at 135 .

49. See, e.g., Günther Handl, State Liability for Accidental Transnational Environmental Damage by Private Persons, 74 AM. J. INT'L L. 525, 538 (1980) (rejecting the assertion that "[a]n even clearer illustration of the application of strict liability in the context of environmental injury is the Gut Dam arbitration ..." and that the tribunal was "clearly adopting a standard of strict liability." (quoting JAN SCHNEIDER, WORLD PUBLIC ORDER OF THE ENVIRONMENT: TOWARDS AN INTERNATIONAL ECOLOGICAL LAW AND ORGANIZATION 165.66 (1979)).

50. See id. at 538-39; see also RENÉ LEFEBER, TRANSBOUNDARY ENVIRONMENTAL INTERFERENCE AND THE ORIGIN OF STATE LIABILITY 103 (1996).

51. See Gabčíkovo-Nagymaros Project (Hung./Slovk.), Judgment, 1997 I.C.J. 7, 17-18 (Sept. 25).

52. See id. at 25. By 1997, Slovakia had (together with Czechoslovakia, of which Slovakia was formerly a part) spent over $\$ 2$ billion on the project and the country's future economic development relied heavily on power generated by the dam. At the same time, Hungary had an interest in preventing the ecological damage the dam had the potential to produce, "including harm to river bank fauna and flora, damage to fish breeding, damage 
Czechoslovakia began investigating alternative solutions and on October 15, 1992, Czechoslovakia unilaterally diverted the Danube within its territory and proceeded to dam the river. ${ }^{53}$ Environmentalists hoped that the International Court of Justice (ICJ) would issue a ruling protecting the Danube ecosystem. ${ }^{54}$ This did not happen. The ICJ upheld the principle of equitable and reasonable utilization-the same principle outlined in the Helsinki Rules. 55 The ICJ found that Hungary had improperly suspended and abandoned the Nagymaros project;56 that Czechoslovakia properly considered a provisional solution, but erred in putting it into operation; 57 and that Hungary's declaration did not have the legal effect of terminating the treaty. ${ }^{58}$ The ICJ found that Hungary had an essential interest in protecting its environment, but that this interest could have been protected by means other than termination of the project. ${ }^{59}$

While the Gabčikovo-Nagymaros holding stands for the principle of equitable and reasonable utilization, the separate opinion of Judge Weeramantry demonstrates the increased role of environmental law principles in watercourse conflicts. Judge Weeramantry utilized the occasion to write an elaborate treatise on the role of sustainable development in settling environmental disputes, discussing the competing interests at stake in major development schemes like the Gabčikovo-Nagymaros Dam and stating, "[t]here is always the need to weigh considerations of development against environmental considerations, as their underlying juristic bases-the right to development and the right to environmental protection-are important principles of current international law."60

to surface water quality, eutrophication, damage to the groundwater régime, agriculture, forestry and soil, deterioration of the quality of drinking water reserves, and sedimentation." Id. at 89 (separate opinion of Vice-President Weeramantry).

53. See id. at 25-27 (majority opinion). In the meantime, Hungary, on May 19, 1992, formally declared the 1977 treaty terminated. Id.

54. HUNTER, SALZMAN \& ZAELKE, supra note 17 , at 867.

55. See Salman, supra note 37 , at 634 .

56. Gabč́kovo-Nagymaros Project, 1997 I.C.J. at 46.

57. See id. at $\mathbf{5 4}$.

58. Id. at 69 .

59. See id. at $\mathbf{4 0 - 4 5}$

60. HUNTER, SALZMAN \& ZAELKE, supra note 17, at 341-42; Gabčíkovo-Nagymaros Project, 1997 I.C.J. at 89 (separate opinion of Vice-President Weeramantry). Judge Weeramantry argued that the principle of sustainable development pays due regard to both developmental and environmental concerns and is an integral part of modern international law: "[Sustainable development] offers an important principle for the resolution of tensions between two established rights. It reaffirms in the arena of international law that there must be both development and environmental protection, and that neither of these rights can be neglected." Id. at 95 . He also went on to say that 
From an environmentalist standpoint, it is also significant that environmental concerns played a central role in Hungary's arguments, demonstrating that environmentalism had come to play a much more prominent role in the law of international watercourses by 1997.

International environmental law principles came further into the fold of the customary international law of watercourses as the United Nations Convention on the Law of the Non-Navigational Uses of International Watercourses and the Berlin Rules on Water Resources each incorporated the obligation not to cause environmental harm-one of the central principles of international environmental law. ${ }^{61}$ The obligation not to cause environmental harm has been codified in the Stockholm Declaration of the United Nations Conference on the Human Environment (1972) [Stockholm Declaration] and the Rio Declaration on Environment and Development (1992) [Rio Declaration], two cornerstone instruments of international environmental law. These declarations pronounce that states are under a general obligation not to cause harm to other states. ${ }^{62}$ In 1996 , the ICJ clearly confirmed that environmental harms are among those harms not to be caused. ${ }^{63}$

Inspired in part by the Helsinki Rules, in 1970 "the Sixth Committee of the UN General Assembly requested [that] the International Law Commission (ILC) address the progressive development of the international law of watercourses." 64 The ILC issued

"development cannot be pursued to such a point as to result in substantial damage to the environment within which it is to occur . . . [D]evelopment can only be prosecuted in harmony with the reasonable demands of environmental protection." Id. at 92. Judge Weeramantry urged that the principles of trusteeship of Earth's resources, intergenerational rights, and symmetry of development and conservation are principles that modern society should attempt to implement:

Land is to be respected as having a vitality of its own and being integrally linked to the welfare of the community. When it is used by humans, every opportunity should be afforded to it to replenish itself. Since flora and fauna have a niche in the ecological system, they must be expressly protected. There is a duty lying upon all members of the community to preserve the integrity and purity of the environment.

Id. at 110. Note that, in his description of the sustainable development model, Judge Weeramantry places environmental protection on an equal plane with development, the modern trend has been to value development over conservation. The following section will elaborate on this point.

61. HUNTER, SALZMAN \& ZAELKE, supra note 17, at 502.

62. Id. at 502-04.

63. Id. at 504. "The existence of the general obligation of States to ensure that activities within their jurisdiction and control respect the environment of other States or of areas beyond natural control is now a part of the corpus of international law relating to the environment." Id. (quoting Legality of the Threat or Use of Nuclear Weapons, Advisory Opinion, 1996 I.C.J. 226, ๆ 29 (July 8)).

64. HUNTER, SALZMAN \& ZAELKE, supra note 17 , at 868 . The International Law Commission "is a UN body composed of legal experts nominated by states, elected by the 
a set of draft articles for non-navigational uses of international watercourses in 1990 that were revised and negotiated over the next seven years to produce the U.N. Convention on the Law of the NonNavigational Uses of International Watercourses in 1997 (U.N. Convention) ${ }^{65}$ Like the Helsinki Rules, the U.N. Convention expounds the principle of equitable and reasonable utilization: "Watercourse States shall in their respective territories utilize an international watercourse in an equitable and reasonable manner."66 However, the U.N. Convention also expressly includes an obligation not to cause significant harm: "Article 7(1) of the Convention obliges watercourse states, when utilizing an international watercourse in their territory, to take all appropriate measures to prevent the causing of significant harm to other watercourse states." 67 The Convention is not expressly clear as to which of these seemingly conflicting principles takes precedence. ${ }^{68}$

Generally, "lower riparian states favour the no harm rule," while "upper riparian states favour the equitable and reasonable utilization principle," which provides more leeway for states to utilize "their share of the watercourse" in ways that may impact downstream states. ${ }^{69}$ "Agreement on which rule takes priority has proven elusive and the issue dogged the ILC throughout its work on the Convention." "70 "[T] prevailing view is that the [UN] Convention has . . . subordinated the obligation not to cause significant harm to the principle of equitable and reasonable utilization." ${ }^{1}$ Due to this and other criticisms, the U.N.

UN General Assembly, and is tasked with the codification and progressive development of international law." Salman, supra note 37, at 631.

65. HUNTER, SALZMAN \& ZAELKE, supra note 17 , at 868 .

66. United Nations Convention on the Law of the Non-Navigational Uses of International Watercourses 4, May 21, 1997, 36 I.L.M. 700.

67. Salman, supra note 37 , at 633 .

68. See id.

The new language of Article 7 requires the state that causes significant harm to take measures to eliminate or mitigate such harm 'having due regard to Articles 5 and 6.' Those two Articles deal with the principles of equitable and reasonable utilization .... However... the prevailing view is that the Convention has ... subordinated the obligation not to cause significant harm to the principle of equitable Id. and reasonable utilization.

69. Salman, supra note 37, at 633 .

70. Id.

71. Id. 
Convention never obtained the requisite number of signatures and ratifications to enter into force. ${ }^{72}$

At the same time that the ILC was drafting the U.N. Convention, the ILA continued developing international water law. ${ }^{73} \mathrm{By}$ the late 1990 s, with rules and provisions scattered throughout multiple instruments, the ILA decided that it was necessary to consolidate the international law of water resources. ${ }^{74}$ In a departure from both the Helsinki Rules and the U.N. Convention, the 2004 Berlin Rules on Water Resources [Berlin Rules] present the right of equitable and reasonable utilization and the obligation not to cause harm on an equal plane. ${ }^{75}$ The Berlin Rules emphasize that the right to an equitable and reasonable share of water resources carries with it duties to other users; ${ }^{76}$ the obligation not to cause harm is a condition of that right. In addition, more so than the Helsinki Rules or U.N. Convention, the Berlin Rules incorporate environmental provisions into the law of international watercourses. The Berlin Rules provide that "[s]tates shall take all appropriate measures to protect the ecological integrity necessary to sustain ecosystems dependent on particular waters"; they expound the precautionary principle; and they include rules regarding ecological flows, alien species, hazardous substances, pollution, and water quality standards. ${ }^{77}$

While the Berlin Rules illustrate the progressive trend toward conservation of water quality and ecological services, it is necessary to recall that both the Helsinki and Berlin Rules are "soft law," intended to act as guidance, and are not legally binding. As the Lake Lanoux arbitration, the Gut Dam Claims, and the Gabčikovo-Nagymaros case suggest, absent an agreement to the contrary, it can be very difficult to enforce customary international environmental law, especially given the human right to development, which will be discussed further in the following subsection.

72. See, e.g., HUNTER, SALZMAN \& ZAELKE, supra note 17, at 868-69. The Convention only ever achieved sixteen signatories, far short of the thirty-five necessary to enter into force. Id.

73. See Salman, supra note 37, at 630. In 1972 the ILA issued its Articles on Flood Control, in 1976 it issued Rules on Administration of International Watercourses, in 1980 it issued rules dealing with regulation of water-flows and the relationship between international water resources and other natural resources, in 1982 it issued articles on pollution, and in 1986 it issued Complementary Rules Applicable to International Water Resources, clarifying the Helsinki Rules. Id. at 630-31.

74. See id. at 631.

75. Id. at 637 .

76. Id. at 636-37.

77. See BERLiN RULes on WATER RESOURCES, art. 22-28, in INTERNATIONAL LAW ASSOCIATION, REPORT OF THE SEVENTY-FIRST CONFERENCE, BERLIN 334 (2004), available at http://www.internationalwaterlaw.org/documents/intldocs/ILA_Berlin_Rules-2004.pdf. 


\section{B. International Environmental Law: Sustainable Development Dialogue Has Weakened Formerly Extant Principles of Environmental Protection}

The Stockholm and Rio declarations are the key instruments that developed out of a broader understanding of the complexity and global nature of the world's environmental problems. ${ }^{78}$ However, when one compares the Stockholm and Rio declarations, it becomes clear that international environmental law underwent a major shift between 1972 and 1992, from a primary emphasis on environmental protection goals to an emphasis on sovereign rights to develop. ${ }^{79}$

The Stockholm Declaration "is generally regarded as the foundation of modern international environmental law," and was the first major event legitimizing environmental policy as an international issue. ${ }^{80}$ Significantly, the Stockholm Declaration contained language recognizing that human beings are but one element in a greater ecosystem, and it seemed to acknowledge that human activity must inevitably be limited by ecological constraints. ${ }^{81}$ Although the overall tone of the declaration was inarguably anthropocentric, at the same time the Stockholm Declaration did recognize a human duty to nature. ${ }^{82}$

The Rio Declaration purportedly intended to elaborate on the rights and obligations first addressed in the Stockholm Declaration, but in actuality it served to unravel the key principles established in Stockholm by pushing an agenda of state sovereignty, economically motivated development, and anthropocentrism. ${ }^{83}$ Basically, the Rio

78. See Marc Pallemaerts, International Environmental Law from Stockholm to Rio: Back to the Future?, 1 REV. EUR. CMTY. \& INT'L ENVTL. L. 254, 254 (1992); Elizabeth Economy \& Miranda A. Schreurs, Domestic and International Linkages in Environmental Politics, in The InTERnationalization of EnVIRonMenTal Protection 1, 2 (Elizabeth Economy \& Miranda A. Schreurs eds., 1997).

79. See David P. Fidler, Challenges to Humanity's Health: The Contributions of International Environmental Law to National and Global Public Health, 31 ENVTL. L. REP. 439, 442-43 (2001).

80. Pallemaerts, supra note 78 , at 255 .

81. See id. at 260 .

[Man] bears a solemn responsibility to protect and improve the environment for present and future generations .... The natural resources of the earth including the air, water, land, flora and fauna and especially representative samples of natural ecosystems must be safeguarded .... Man has a special responsibility to safeguard and wisely manage the heritage of wildlife and its habitat.

United Nations Conference on the Human Environment, Stockholm, June 5-16, 1972, Declaration of the United Nations Conference on the Human Environment 3, U.N. Doc. A/CONF,48/14 (June 16, 1972).

82. Pallemaerts, supra note 78 , at 260 .

83. See id. at 256. 
Declaration placed a strong emphasis on development, which upset the balance "between sovereign use of natural resources and duty to care for the environment." 84

Rather slyly, the Rio Declaration places its discussion of development within the realm of human rights law, affirming a "right to development." 85 However, in practice, this "right" is actually a right of states, not of individuals. ${ }^{86}$ The "right to development" provision represents the "precedence of national economic sovereignty over international environmental obligations"-not an attempt to fulfill human rights. ${ }^{87}$ The Rio Declaration also fails to include any references to the intrinsic value of natural ecosystems and nonhuman species similar to references that appeared in the Stockholm Declaration. ${ }^{88}$ Instead, the Rio Declaration states, "human beings are at the centre of concerns for sustainable development." 89

The policy shift between the Stockholm and Rio Declarations can be best explained as a result of differing interpretations of international environmental duties between developed and developing countries, what Professor David Fidler calls, "the bitter politics of North-South relations" in which "[t]ensions between developed and developing countries mark the politics of [many] international environmental

84. Id.

85. See, e.g., id. at 259. "States have, in accordance with the Charter of the United Nations and the principles of international law, the sovereign right to exploit their own resources pursuant to their own environmental and development policies." United Nations Conference on Environment and Development, Rio de Janeiro, June 3-14, 1992, Rio Declaration on Environment and Development 1, U.N.Doc. A/CONF.151/5/Rev.1 (June 13, 1992) [hereinafter Rio Declaration].

86. Pallemaerts, supra note 78 , at 259.

87. Id. Additionally, the Rio Declaration lacks any language affirming a human right to a viable environment. Prior to the United Nations Conference on Environment and Development (UNCED), there were proposals which built upon the Stockholm Declaration and aimed to codify a human right to a healthy environment. One proposed provision stated, "[A]ll human beings have the fundamental right to an environment adequate for their health and well-being." Id. at 259. This proposal would, in effect, establish international obligations among States as well as between States and individual victims. Other proposed principles included individual rights of access to environmental information, right of citizen participation in environmental decisionmaking, and rights of access to administrative and judicial proceedings. Id. at 260 . "There was an obvious reluctance" on the part of participating Member States at UNCED to accept the possibility of individual rights and obligations existing under international environmental law independent of national legal systems and so this species of provision was largely left out of the Rio Declaration. Id. at 259. What survived were watered-down, vague statements, such as, "[E]nvironmental issues are best handled with the participation of all concerned citizens at the relevant level." Id. at 260 .

88. Id.

89. Rio Declaration, supra note 85 , at 1 . 
problem[s] and create a difficult milieu in which to protect the environment."90 Basically, tensions between environmental conservation and state development mirror structural and material inequalities in international relations between developed and developing states. ${ }^{91}$ The shift from environmentalism to development is explained by the fact that developing countries, which did not have an opportunity to participate in the Stockholm Conference, pushed for a focus on development when they were given the opportunity to participate in the Rio Conference.

"Economically, conservation requires the state to forgo benefits of further exploitation . . . while incurring costs in preserving the resource."92 Thus, the "North-South" tension stems from the fact that developing states, whose priority is economic development, see environmental protection as a luxury and international environmental law as an intrusion on state sovereignty. ${ }^{93}$ They feel that developed countries are attempting to unfairly force them to shoulder the financial and technical burdens of conservation. ${ }^{94}$ In this context, international law is characterized by a clash between traditional international legal principles of state sovereignty over natural resources and nonintervention in the domestic affairs of states on the one hand and equally longstanding norms of state responsibility and the doctrine of the abuse of rights, coupled with newly emerging customs and environmental treaties, on the other. ${ }^{95}$

For these reasons, "[t]he Rio Declaration smothers international environmental law and policy by merging it, as it were, with international economic law and development law."96 The Rio Declaration does not import the term "international environmental law," instead referring to "sustainable development", and actually warns that, in the future, environmental considerations will have to be balanced with developmental ones. ${ }^{97}$ This tension between environmental protection and the right to develop is mirrored in the tension between the obligation not to cause harm and the right to reasonable and equitable use, which we saw in the context of the law of international watercourses. The fact that any environmental obligations placed on states will be diluted or neutralized by these rights makes it

90. Fidler, supra note 79 , at 441-42.

91. Id. at 467 .

92. Id. at 441 .

93. See id.

94. See id.

95. See id. at 441-42.

96. Pallemaerts, supra note 78 , at 263.

97. Id. at 264 . 
very difficult to compel any uncooperative state to conserve its freshwater resources.

\section{The Shortcomings of International Environmental Protection of Freshwater Resources}

Neither the traditional law of international watercourses nor the more modern trend of combining international environmental law with watercourse management are capable of fully considering the needs of freshwater ecosystems or ensuring a sustainable model of use and consumption. The international law of watercourses is not really about environmental protection; its focus is on navigation and development of international watercourses. And, as we have seen, international environmental law is too weak to adequately protect freshwater ecosystems, and is actually growing weaker.

[D]espite the growing focus on the total availability of freshwater and the need to ensure access to freshwater [which we saw in the UN Freshwater Assessment], most international water law continues to relate primarily to transboundary or shared watercourses .... [T] he law has developed more with respect to transboundary watercourses than to freshwater generally, and more with respect to the allocation and use of those water courses [sic] than to more recent interests like environmental protection or human rights to access water. ${ }^{98}$

This is the backdrop that brings us to the present movement for a human right to water. Some environmentalists feel that a human right to water might be a way to finally address these environmental issues. However, as we examine the human right to water, bear in mind the findings of the U.N. Freshwater Assessment and consider whether a human right to water is capable of addressing the environmental concerns expressed therein.

\section{THE HUMAN RIGHT TO WATER}

\section{A. Sources and Development of the Right to Water}

The fact that two separate United Nations bodies felt the need to clarify that there is in fact a legally binding human right to water,

98. HUNTER, SALZMAN \& ZAELKE, supra note 17 , at 848-49. 
contained in the International Covenant on Economic, Social and Cultural Rights (ICESCR), is evidence in itself that the existence of a human right to water is a contentious topic. Various advocates and proponents have debated whether there is a recognized right to water, whether such a right is legally binding, and from which international law instrument it is derived. Although there are other sources of human rights to water, such as treaties and state constitutions, this Section will focus on the development of the right to water within the United Nations framework.

The United Nations' International Bill of Rights is comprised of the Universal Declaration of Human Rights (UDHR); the International Covenant on Economic, Social and Cultural Rights (ICESCR); and the International Covenant on Civil and Political Rights (ICCPR). Each of these instruments contains some provision from which a right to water could arguably be derived but none unequivocally declares a right to water. ${ }^{99}$ Proponents of the right to water have inferred this right as a fundamental condition for achieving the right to life and the right to health. 100

99. The UDHR guarantees all people the right to a standard of living adequate for health and well-being. Universal Declaration of Human Rights, G.A. Res. 217 (III), U.N. Doc. A/RES.217(III), at art. 25 (Dec. 10, 1948) [hereinafter UDHR]. Article 11 of the ICESCR recognizes "the right of everyone to an adequate standard of living for himself and his family, including adequate food, clothing and housing," while Article 12 recognizes "the right of everyone to the enjoyment of the highest attainable standard of physical and mental health." International Covenant on Economic, Social and Cultural Rights, G.A. Res. 2200 (XXI), U.N. Doc. A/6316, at art. 11, 12 (Dec. 16, 1966) [hereinafter ICESCR]. It should be noted that rights provided for under the ICESCR are achieved progressively and considered aspirational, rather than true individual rights. See SALMAN M. A. SALMAN \& Siobhán MCINERNEY-Lankford, The Human Right to Water: Legal and POLICY Dimensions, 28-29 (David Freestone \& Salman M. A. Salman eds., 2004). Conversely, the ICCPR conveys an immediate obligation onto Member States to respect and ensure the rights specified therein. See Ling-Yee Huang, Note, Not Just Another Drop in the Human Rights Bucket: The Legal Significance of A Codified Human Right to Water, 20 FLA. J. INT'L L. 353, 356 n.17 (2008); SALMAN \& MCINERNEY-LANKFORD, supra at 99. A right to water could be derived from the ICCPR's inherent right to life, however, the amount of water supported by a right to life "ensures only the barest minimum quantity ... . necessary to support life . . . [and] does not ensure water sufficient for personal consumption or even for all forms of hygiene." Erik B. Bluemel, The Implication of Formulating a Human Right to Water, 31 ECOLOGY L.Q. 957, 968 (2004).

100. See Bluemel, supra note 99, at 968 . The right to water has also been inferred from the language, "everyone has the right to a standard of living adequate for the health and well-being of himself and his family, including food," which appears in Article 25 of the UDHR and Article 11 of the ICESCR, the argument being that a right to water is implicit in the right to an adequate standard of living due to the fundamental necessity of water for human survival. UDHR, supra note 99, at art. 25; ICESCR, supra note 99, at art. 11; see also Bluemel, supra note 99, at 968; Malgosia Fitzmaurice, The Human Right to Water, 18 FORDHAM ENVTL. L. REV. 537, 540 (2007); ASHFAQ KHALFAN \& THORSTEN KIEFER, WHY 
In 2000, the United Nations Committee on Economic, Social and Cultural Rights adopted General Comment 14, which "interpret[ed] the right to health as an inclusive right extend[ing] not only to timely and appropriate healthcare but also to those factors which determine good health."101 Then, in 2002, General Comment 15 confirmed that "the right to water clearly falls within the category of guarantees essential for securing an adequate standard of living, as it is one of the most fundamental conditions for survival."102 General Comment 15 refers back to the ICESCR, noting the necessity of water for achieving the covenant's named rights. ${ }^{103}$ At the same time, General Comment 15 also bypasses some of the difficulties associated with attempting to imply the right to water out of other named rights by recognizing it as an independent right. ${ }^{104}$

In the eight years following General Comment 15, various United Nations resolutions and decisions contemplated the necessity of formally recognizing a human right to water. ${ }^{105}$ Finally, on July 28,

Canada Must Recognize the Human Right to Water and SANitation 6 (2008) (Switz.), available at http://www.righttowater.info/pdfs/canada-must-recognize-right-to-water.pdf. Following the example of the International Bill of Human Rights, the Convention on the Elimination of All Forms of Discrimination against Women (1979), the Convention on the Rights of the Child (1989), and the Convention on the Rights of Persons with Disabilities (2006) all contain provisions for an adequate standard of living and each name water supply, sanitation, or clean water as lesser included rights. See KHALFAN \& KIEFER, supra at 100 .

101. LindSAY KNIGHT, THE Right To WATER 8 (2003). General Comments, issued by the United Nations Committee on Economic, Social and Cultural Rights, are reflections on the experience the Committee has gained by conducting reports on various rights and issues of the covenants. These comments cannot create new rights or obligations, but elaborate on and clarify the existing rights and obligations contained in the ICESCR. As such, General Comments, though nonbinding and advisory in nature, have significant bearing on the enforcement, realization, and observance of the ICESCR. E.g., SALMAN \& MCINERNEY-LANKFORD, supra note 99, at 53.

102. U.N. Committee on Economic, Social, and Cultural Rights, General Comment No. 15 - The Right to Water, If 3, U.N. Doc. E/C.12/2002/11 (Jan. 20, 2003) Thereinafter General Comment No. 15]. Despite its status as a mere General Comment, this was the first document produced by the United Nations recognizing an independent human right to water that could be relied upon in determining whether a state has met its ICESCR obligations. See Huang, supra note 99, at 356; Bluemel, supra note 99, at 971-72.

103. See General Comment No. 15, supra note 102, at \1; see also Huang, supra note 99 , at 357 .

104. See General Comment No. 15, supra note 102, at I 1; see also Bluemel, supra note 99 , at 971 .

105. On November 27, 2006, the United Nations Human Rights Council issued Decision 2/104, reaffirming the above mentioned treaties as well as General Comment 15 and requesting a detailed study from the United Nations High Commissioner on the "scope and content of the relevant human rights obligations related to equitable access to safe drinking water and sanitation under international human rights instruments . . ." Human Rights 
2010, the General Assembly adopted Resolution 64/292, formally recognizing access to safe and clean drinking water and sanitation as a human right. The UNHRC followed suit on September 24, 2010 by affirming this decision.

\section{B. Substantive Content of the Right to Water}

Unfortunately, although Resolution 64/292 affirmed the human right to water, it failed to elaborate on the substantive content of that right, instead referring back to the above-mentioned treaties and General Comment 15.106 Therefore, General Comment 15 offers the best information on the substantive content of the right to water.

General Comment 15 affirms the right to water as an obligation under the ICESCR, as it is essential for subsistence and environmental hygiene--again, tracing the right to water back to the rights to an adequate standard of living and to health. ${ }^{107}$ According to General Comment 15, the right to water consists of freedoms and entitlements: the freedom to maintain access to existing, necessary water supplies, the right to be free from interferences in doing so (such as disconnections and contamination), and the entitlement to a system of water supply and management that provides everyone with an equal opportunity to enjoy water adequate for maintaining human dignity, life, and health. 108

Immediate state obligations emanating from the right to water include the guarantee that the right will be enforced without discrimination of any kind and that states will take deliberate, concrete steps toward the full realization of the right. ${ }^{109}$ The "core obligations" of U.N. Member States are to ensure the following:

Council Dec. 2/104, Human Rights and Access to Water, 2nd Sess., Sept. 18 - Oct. 6 \& Nov. 27-29, 2006, UN Doc. A/HRC/2/9 at 17 (Mar. 22, 2007). On March 28, 2008, the Human Rights Council issued Resolution 7/22, a special resolution proposed by Germany and Spain, but the proposal did not go exactly as desired because although the resolution established an independent expert to further consider the parameters of human rights obligations related to access to safe drinking water and sanitation, as the result of opposition from Canada, the resolution was stripped of references that recognized access to water as a human right and the idea of creating an international watchdog organization was abandoned. E.g., Mike DeSouza, UN Rejects Water as Basic Human Right, CANADA.COM (Mar. 25, 2008) (Can.), http://www.canada.com/topics/news/world/story.html?id=b65b35fd-477f-4956-98f4c17a46fe3e26.

106. See G.A. Res. 64/292, U.N. GAOR, 64th Sess., U.N. Doc. A/RES/64/292 (Aug. 3, 2010).

107. See General Comment No. 15, supra note 102, ๆ 11.

108. See id. \10.

109. See id. I 17. 
(1) a minimum amount of water for personal and domestic use; (2) non-discriminatory treatment with respect to the availability, accessibility, and quality of water; (3) safe physical access to water facilities large enough to support its population's needs reasonably ... (4) the creation of a national water plan and strategy; (5) monitoring of the realization of the right to water; (6) the adoption of low-cost programs to ensure the right to vulnerable and marginalized populations; and (7) measures exist to limit [exposure] to water-borne disease. ${ }^{110}$

Other obligations on Member States consist of obligations to respect, protect, fulfill, and provide international assistance and cooperation in order to enable developing countries to fulfill their core obligations as well. ${ }^{111}$ The obligation to respect prohibits any actions that undermine the right to water, requiring that states refrain from interfering either directly or indirectly with individuals' right of enjoyment.112 The obligation to protect requires that states implement regulatory systems to control third-party, private-actor behavior that could potentially interfere with the right to water. ${ }^{113}$ Thus, states are under an obligation to prevent private suppliers of water from compromising equal, affordable, and physical access to adequate water. ${ }^{114}$ The obligation to fulfill places a responsibility on states to facilitate enjoyment of the right to water; promote the right to water through education measures; and in cases where individuals cannot realize the right to water due to financial or other constraints beyond their control, provide water necessary for realization. ${ }^{115}$ States are also required to progressively extend their sanitation services to rural and deprived urban areas. ${ }^{116}$

110. Bluemel, supra note 99 , at 976 .

111. See General Comment No. 15, supra note 102, ๆ 20.

112. Id. ๆ 21. This includes prohibiting activities such as pollution from State-owned facilities. E.g., Bluemel, supra note 99, at 973.

113. E.g., Bluemel, supra note 99, at 973. This includes regulation of third-party polluters, third-party extractors of water, and even third-party water suppliers who might interfere with realization of the right to water. General Comment No. 15, supra note 102, I 23-24.

114. See General Comment No. 15 , supra note 102, If 24 . This obligation necessarily entails "independent monitoring, public participation, and imposition of penalties for noncompliance." Id.

115. See id. at ๆ 26 .

116. Id. \ 29. General Comment 15 recommends that States meet their obligation to fulfill by recognizing the right to water within their national legal systems, adopting a national water strategy or plan of action, and ensuring that water is affordable for everyone. See id. ๆ 26. It urges that national water strategies and plans of action be based 
Finally, the right to water requires not only that states refrain from interfering with access to adequate water within their borders, but also that they respect the enjoyment rights of other states. ${ }^{117}$ Depending on the availability of their resources, states are also urged to aide other countries in the realization of the right to water. ${ }^{118}$

\section{Monitoring and Compliance for the Right to Water}

General Comment 15 provides that states "must establish that they have taken necessary and feasible steps towards the realization of the right to water" and show that they have acted in good faith. ${ }^{119}$ General Comment 15 also provides that States have "a margin of discretion in assessing what measures are suited to their particular circumstances." 120 Again, the 2010 resolutions do little to flesh out these principles. On September 24, 2010, the UNHRC simply reaffirmed "the fact that international human rights law instruments, including the International Covenant on Economic, Social and Cultural Rights [and other conventions] entail obligations for States in relation to access to safe drinking water and sanitation."121

Under the ICESCR, state violations can occur either through acts of commission-such as retrogressive measures, repeal or suspension of legislation, or adoption of legislation or policies that conflict with the right to water-or acts of omission-such as failure to take appropriate

upon human rights law; cover all aspects of the right to water; define clear objectives and set targets or goals with corresponding benchmarks and indicators; and establish institutional responsibility for this process, identifying and allocating resources and establishing accountability mechanisms. See id. I 47. It further urges that these strategies and plans be nondiscriminatory and invite individual and group participationpublic participation should be an integral part of water policy making. See id. I 48 .

117. States must take steps to ensure that their own citizens and companies do not violate the right to water in other countries as well. See id. ๆ33. Violation of the right to water necessarily includes embargos and other means of political and economic pressure when applied to water. See id. I 32. States are also required to take the right to water into consideration when entering into trade agreements or formulating international lending

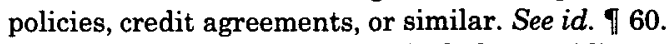

118. Id. I 34. This could include providing water, providing financial or technical assistance, or even providing emergency aid. Id. This provision of General Comment 15 seems to be the chief reason why Canada was reluctant to recognize the right to water in 2008. Canada was concerned that a U.N. resolution on the right to water could require Canada to provide bulk exports of water to the United States. However, this view was largely mistaken; the provision concerns only necessary aid and not, as one official put it, "water for swimming pools and golf courses and fountains." See DeSouza, supra note 105.

119. General Comment No. 15, supra note 102, ๆ 40.

120. Id. \ 45.

121. U.N. Human Rights Council, 15th Sess. Agenda Item 3 - Human Rights and Access to Safe Drinking Water and Sanitation, U.N. Doc. A/HRC/15/L.14 (Sept. 24, 2010). 
steps toward realization of the right to water, failure to have a national policy on water, or failure to enforce relevant laws. ${ }^{122}$ States that are found to have violated the ICESCR "may be fined and ordered to adopt specific remedial plans to address their violations." 123

\section{The State of the Planet's Freshwater Resources and the Right to Water}

Considering the fact that " 1.1 billion people live without safe drinking water[,] 2.6 billion people do not have access to adequate sanitation[, and g]lobally, almost 6000 children under the age of five die every day from water related diseases," the human right to water is a noble cause. ${ }^{124}$ The problem, from an environmentalist standpoint, is that the right to water is about human consumption, not conservation or sustainability. Despite the fact that General Comment 15 and the 2010 resolutions call for an increased level of consumption that would most likely require increased development and increased infrastructure as well, not one of these instruments, in any part, discusses conservation, sustainability, or the preservation of freshwater ecosystems. ${ }^{125}$.

The fact is that environmental protection and human rights simply have differing objectives. For example, the "obligation to protect" requires that states and private actors refrain from interfering with the right of enjoyment-environmental regulations by their nature interfere with rights of enjoyment. ${ }^{126}$ Human rights necessarily focus on human needs and any human right to a healthy environment, let alone a healthy freshwater ecosystem, will never take priority over a right to water, other rights to consumption, or even the right to develop. Despite some proponents' high hopes that, by "provid[ing] further impetus to efforts to improve the availability of freshwater and sanitation services,"

122. See General Comment No. 15, supra note 102, ๆ 42-43.

123. Bluemel, supra note 99, at 976. The Committee on Economic, Cultural and Social Rights has the authority to investigate, fact-find, and issue judgments regarding the implementation of ICESCR obligations and to conduct administrative law functions such as holding hearings and receiving reports from third-parties. See SALMAN \& MCINERNEYLANKFORD, supra note 99, at 41. However, despite the fact that General Comment 15 states, "Any persons or groups who have been denied their right to water should have access to effective judicial or other appropriate remedies at both national and international levels," the comment does not elaborate on what international remedies may be available. General Comment No. 15, supra note 102, I 55. The fact is that under the ICESCR there is not a procedure for individual communications or individual petitions. SALMAN \& MCINERNEY-LANKFORD, supra note 99, at 42.

124. Fitzmaurice, supra note 100 , at 538.

125. See General Comment No. 15, supra note 102; see also G.A. Res. 64/292, U.N. GAOR, 64th Sess., U.N. Doc. A/RES/64/292 (Aug. 3, 2010).

126. See e.g., Fidler, supra note 79 , at 441. 
the human right to water might actually lead to restoration of freshwater ecosystems, the fact is that environmental protection of freshwater resources is simply not achievable through the human rights framework. ${ }^{127}$

\section{INCREASING HUMAN ACCESS TO WATER IN A CONTEXT OF EXPANDING ENVIRONMENTAL DEGRADATION: WILL EFFORTS TO FULFILL THE HUMAN RIGHT TO WATER CONTRIBUTE TO NATIONAL AND INTERNATIONAL ENVIRONMENTAL PROBLEMS WITH WATER SCARCITY?}

Human rights and environmental law share many similarities; "[1]ike human rights, environmental law houses a hidden imperial ambition; both potentially touch upon all spheres of human activity, and claim to override or trump other considerations." ${ }^{28}$ However, fundamental tensions exist between these two bodies of law. The priority that human rights advocates accord to humans, "potentially at the expense of natural ecological processes," is at odds with the conservation goals of environmentalism. ${ }^{129}$

If the established human rights to life, health, property, culture, and decent living conditions are to be fulfilled for the majority of the global population rather than just a minority, and if those rights are realized in the pursuit of affluence rather than moderation, then a rapid depletion of natural resources is a likely consequence. ${ }^{130}$

Thus, from an environmentalist standpoint, "there is a structural contradiction between fulfilling existing rights for a growing population and effective protection of limited environmental goods." 131

It is not my position that the law of international watercourses does a better job of protecting the environment than the human right to water; both areas of law are extremely lacking in environmental

127. Fitzmaurice, supra note 100 , at 553 .

128. Michael R. Anderson, Human Rights Approaches to Environmental Protection: An Overview, in Human Rights ApProaches to ENVIRONMENTAL PRotection 1, 1 (Alan E. Boyle \& Michael R. Anderson eds., 1996). Human rights and environmental law share common goals, both aiming to reduce the domain of domestic jurisprudence and restrain the power of governments and private actors. In fact, "[t]here is an increasing tendency for environmentalists and human rights activists to work together ... [and] there is a natural affinity between" environmental and human rights organizations at the international level. Id. at 2.

129. See id. at 3 .

130. Id.

131. Id. 
consideration. Furthermore, although international environmental law is more considerate of the environment, as a resource for environmental protection it is notably weak. My point is that if we consider environmental protection to be a priority, the human right to water, in its current form, is not the best direction for international water law to take.

The issue of water scarcity brings up numerous environmental concerns, none of which are addressed by the human right to water, which would instead circumvent these competing concerns and decide where water should be allocated without regard for sustainability. $\mathrm{My}$ proposal would be to subject the human right to water to an environmental proviso, in the same way that the Berlin Rules on Water Resources subject the right of equitable and reasonable utilization of an international watercourse to the obligation not to cause environmental harm. Doing so would restrict the right to consumption of freshwater resources based on what the environment is capable of providing, rather than subject the environment to the needs of an exponentially increasing population.

To answer the questions posed in the introduction: the considerably weakened state of international environmental law, following the shift in focus from environmental protection to a right to development, coupled with the potential realization of a human right to water could very well lead to rapid depletion of the planet's freshwater resources. ${ }^{132}$ For this reason, the human right to water is not the best avenue for addressing global water stress issues. Rather, the human right to water is a consideration that must be balanced with a separate mechanism for environmental protection, because without adequate environmental safeguards realization of the human right to water will contribute to environmental degradation.

Implementation of rights under the ICESCR is progressive, not instant. ${ }^{133}$ The right to water will be virtually impossible to implement immediately, even at a minimal level. ${ }^{134}$ I propose that the United Nations take this time to consider drafting a more comprehensive document, codifying the right to water and including adequate environmental safeguards and sustainability provisions.

132. For an argument that this could potentially lead to a societal breakdown, see William Ophuls, The Scarcity Society, HARPER's, Apr. 1974, at 47.

133. See Bluemel, supra note 99 , at 976 .

134. See Fitzmaurice, supra note 100, at 551. 
